\title{
Cognitive-ergonomics and instructional aspects of e-learning courses
}

\author{
Rodrigues, Martha ${ }^{\mathrm{a}^{*}}$; Castello Branco, Iana ${ }^{\mathrm{a}}$; Shimioshi, Joséb ${ }^{\mathrm{b}}$, Rodrigues, Evaldo ${ }^{\mathrm{b}}$; Monteiro, Simone ${ }^{\mathrm{a}}$ \\ and Quirino, Marcelo ${ }^{\mathrm{a}}$ \\ ${ }^{a}$ Universidade de Brasília, Faculdade de Tecnologia, Núcleo de Engenharia de Produção, Campus Darcy \\ Ribeiro, Brasilia-DF, Brasil, 70.910-900, 55-61-3107-5672, marthaveras@unb.br \\ ${ }^{\mathrm{b}}$ Universida de Brasília, Faculdade de Tecnologia, Campus Darcy Ribeiro, Programa de Pós Graduação em \\ Transportes, Brasília-DF
}

\begin{abstract}
This paper presents an analysis of cognitive-ergonomic aspects of e-learning courses, offered by an organism from Brazilian Public Administration. The Cognitive Ergonomic studies conductive and cognitive aspects concerning to the relation between human, physics elements and social elements of the work space. From that usability aspects were evaluated by these points: i) visualization; ii) text comprehension lecture; iii) memory; iv) interface; v) instructional design; and vi) attention and learning. That survey is characterized as having been applied using the following techniques: (1) bibliographic survey, (2) field survey and (3) analysis of the documents. It was chosen the semi-structured questionnaire as the main method of data collection. About the interacting with artifacts, the interface of the courses is classified as direct engagement, because it allows the user to get the feeling that acts directly on the objects. Although the courses are well-structured they have flaws that will be discussed below. Even with these problems, the courses have a good degree of usability.
\end{abstract}

Keywords: Cognitive Ergonomics, E-learning, Usability, Instructional Design and Comprehension Lecture

\section{Introduction}

The e-learning presents an interaction that involves the man and the computer, than the student becomes more than a simple spectator but an active participant in the construction of knowledge.

The cognitive ergonomic helps in the developing of better interfaces for assimilation and understanding of their users allowing for greater usability and maximize efficiency.

With the development of e-learning courses for employees, it's necessary to analyze their adequacy to the organization needs and that constitute it.

About the institution and the object courses of this study:

The House of Representatives - CD has their constitution based on the existence of people's representatives (parliament).

The courses studied were created by the CEFOR, Forming, Training and Improvement of the House of Representatives - Body responsible for the planning, implementation, monitoring and evaluation of the construction of knowledge process.
Linked to the CEFOR has the E-learning Center that develops and teaches courses in distance mode, using printed materials and a virtual learning environment AVA.

The employees of CD development is seeing as a solution for the population to have a new vision of the organization and to achieve its primary goal - attending the population needs.

\section{Methodology}

This research is applied, bibliographic and documentary field. Were used a semi-strutuctured questionnaire for the data collection, with a Lickert scale using the following classification: 1- does not apply; 2- applies to a limited extend; 3- applies; 4- applies to a huge extend and 5- applies totally.

The courses that were considered were the free ones, without students limit per class and half face, with almost thirty students per class, and the closes ones, with no more than thirty students per class.

After several stratifications and many calculations, it was reached a population of 410 students-employees and a sample of 36 asked. 
There aren't repetitions over the content of the courses, which hinders their assimilation.

\section{Result Analysis}

The open course doesn't presented sound. Although, the interface has pictures, images and texts. In the other hand, the close courses and the half face presented as differential the existence of the sound in some modules and figures, animations.

The users identified the following colors as predominant in the interface: (1) blue; (2) green, (3) red, (4) yellow, (5) orange, (6) black and (7) white.

According to the guidelines of Shneiderman (1998), the use of different colors for each 12 items in a menu created a devastating effect. In these interface, as Figure 1, are presented eight colors in the menu, differentiating light blue and dark blue. This facilitates the viewing and makes the interface more pleasing to the navigation. The colors study focuses on finding the formation of an interface that causes the least possible fatigue in its users and if so, there was no claim of fatigue caused by inappropriate use of colors in the interface.

As the taxonomy of Cañas and Waerns (2001) regarding the interaction with artifacts, the interface of the courses are classified as direct engagement, or direct engagement, because it provides the user the feeling that acts directly on the objects. This characteristic is positive, because it allows the student to feel more active in their learning process.

There are sentences with embedded structure, which is an expression entered in another sentence, leading to a greater effort of memory to understand synthetic phrases.

There are icons that appear similar and viewing inappropriate some links.

The non-selection of participants according to their profile prevented the development of instructional materials most suited to each specific audience.

\section{References}

[1] Canãs, José \& Waerns, Yvonne. Ergonomia Cognitiva: Aspectos Psicológicos de Lá Interacción de las Personas con la Tecnología de La Información. Madrid: Ed. Médica Panamericana, 2001.

[2] Dix, Alana: et al, Human-Computer Interaction, London: Prentice Hall Europe, 1993.

[3] Lima, Sérgio, Ergonomia Cognitiva e a Interação PessoaComputador: análise da usabilidade de uma urna eletrônica 2002 e do módulo impressor externo, Dissertação de Mestrado, Florianópolis: UFSC, 2003.

[4] Matlin, Margareth, Psicologia Cognitiva, Rio de Janeiro: LTC, 2003.

[5] Melching, Instrucional Objetctives, In MERRILL, David, Instrucional Design: readings, New Jersey: Prentice-hall, 1971

[6] Ramos, Wilsa, A compreensão leitora e a ação docente na produção de texto para a educação à distância, Brasília: Linguagem \& Ensino, Vol. 9, No.1, 2006.

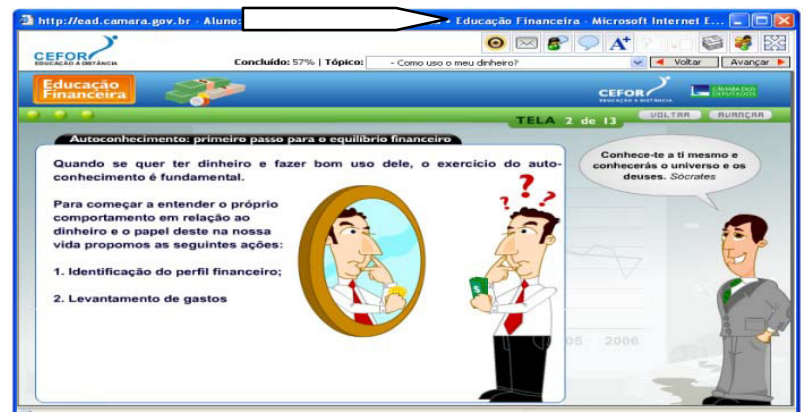

Figure 1 - Colors used in the interface of the wed classes.

The interface of the free courses doesn't have the same facilities as the close and half face courses does, as is the case of the audio features and differentiation of the icons "back and forth".

\section{Conclusions}

The literature considers and the methodology used for the evaluation of the cognitive-ergonomics aspects of the elearning courses of the $\mathrm{CD}$ were suitable to enabling the verification of the important questions for understanding/ learning in virtual environments, leading to the conclusion that despite the problems mentioned, the courses have good usability and promote student learning.

Studies on "cyberculture" complement the usability evaluation of distance learning courses.

[7] Shneiderman, Bem, Designing the user interface: strategics for effective human-computer interaccion, Maryland: AddisonWeslwey Longman, 1998. 